\title{
Simulasi Dan Analisa Efek Doppler Terhadap OFDM Dan MC-CDMA
}

\author{
Ruliyanto, Rianto Nugroho \\ Program Studi Teknik Elektro, Fakukultas Teknik dan Sains, Universitas Nasional Jakarta \\ Korespondensi: Rully_33@yahoo.co.id
}

\begin{abstract}
ABSTRAK. Pada penelitian ini dilakukan Simulasi dan Analisa efek Doppler terhadap OFDM dan Multi carrier CDMA yang menggunakan frekuensi carrier $900 \mathrm{MHz}$ dan 1800 $\mathrm{MHz}$ pada kanal AWGN dengan maksud untuk menghitung pengaruh doppler pada BER (Bit Error Rate) pada kecepatan doppler $20 \mathrm{~m} / \mathrm{s}$ atas penerimaan OFDM dan MC-CDMA. Simulasi dan Analisa ini menggunakan piranti lunak Javascript untuk mendapatkan perbandingan jumlah kesalahan bit (Bit Error Rate) pada OFDM dan MC-CDMA. Dari hasil simulasi dengan menggunakan 2 jenis frekuensi carrier yang berbeda serta menggunakan $\mathrm{E}_{\mathrm{b}}$ / $\mathrm{N}_{\mathrm{o}}$ dari $1 \mathrm{~dB}$ hingga $20 \mathrm{~dB}$ maka BER pada MC-CDMA lebih bagus dari OFDM. Hal ini terlihat dari hasil BER yang dihasilkan, misalnya pada nilai $\mathrm{E}_{\mathrm{b}} / \mathrm{N}_{\mathrm{o}}=12 \mathrm{~dB}$ dengan frekuensi carrier $1800 \mathrm{MHz}$, maka untuk OFDM memiliki nilai BER $=0.0159$ sedangkan pada $\mathrm{MC}$ CDMA memiliki BER $=0.0006$.
\end{abstract}

Kata kunci: Efek doppler, OFDM, MC-CDMA, Kanal AWGN.

\section{PENDAHULUAN}

Struktur penerima Orthogonal Frequency Division Multiplexing (OFDM) memberikan pemrosesan sinyal secara langsung untuk mencegah delay spread secara relatif, dimana tujuan utama adalah untuk menggunakan metode modulasi OFDM. Dalam Digital Audio Broadcasting (DAB), penerimaan bergerak membawa kondisi saluran yang tidak menguntungkan, dengan kedua penyebaran frekuensi dan perubahan saluran yang tumbuh bersamaan dengan waktu. Hasil percobaan lapangan yang diadakan pada musim panas tahun 1999 oleh perusahaan Nokia, Deutsche Telecom, dan ZDF menawarkan komputasi yang bergerak dan penelusuran jaringan atas hubungan penyiaran Digital Terresterial Television Broadcasting (DTTB) dengan sebuah saluran Global System for Mobile Communication (GSM). Hal ini melibatkan penerimaan OFDM atas saluran-saluran dengan sebuah Doppler Spread dan sesuai dengan perubahan waktu, yang dikenal untuk merusak orthogonal pembawa bentuk gelombang OFDM. Dalam hal ini Intercarrier Interference (ICI) sebuah gangguan antar pembawa yang terjadi karena komponen sinyal dari satu pembawa mengalami satu gangguan pada pembawa cadangan di sekitarnya [1].

Multi Carrier Code Division Multiple Access (MC-CDMA) juga menggunakan tipe transmisi OFDM pada pengguna jamak sinkronisasi sinyal Direct Sequence (DS) -CDMA. Pada DSCDMA yang konvensional, setiap penggunanya ada sedikit yang dipancarkan membentuk banyak rangkaian chip, yang mana tiap berdurasi pendek kemudian menjadi sebuah bandwith yang luas. Dengan hal tersebut, karena adanya perubahan OFDM, Chip-chip MC-CDMA menjadi lama dalam durasi waktu, karena sempitnya ruang dalam bandwith [1].

\section{LANDASAN TEORI}

\section{Karakteristik Propagasi pada Kanal Komunikasi Bergerak.}

Pada kanal radio ideal, sinyal yang diterima hanya terdiri dari sinyal langsung tunggal, yang merupakan sinyal yang dipancarkan. Akan tetapi, pada kanal yang sesungguhnya, sinyal mengalami perubahan selama transmisi.

Sinyal yang diterima terdiri dari sinyal yang kirim yang mengalami redaman, pantulan, pembelokan, dan hamburan. Kanal menambahkan derau kepada sinyal dan dapat menyebabkan suatu pergeseran frekuensi pembawa jika pemancar atau penerima bergerak (Effect Doppler) [2]. 
Kanal ideal memiliki respon frekuensi datar (flat) dan respon fasa linier terhadap lebar pita sinyal yang akan dikirim. Kanal yang tidak ideal mengalami distorsi sehingga respon frekuensi tidak datar dan respon fasa tidak linier. Jenis kanal tidak ideal yang paling sederhana adalah kanal AWGN (Additive White Gaussian Noise) yang merupakan sistem transmisi linier yang tidak berubah terhadap waktu (linear time invariant) yang berasal dari derau termal pada penerima. Kanal AWGN terjadi pada komunikasi radio dimana kondisi free space dapat terpenuhi, tanpa adanya lintasan jamak (multipath propagation) [2].

\section{Komunikasi Spektrum Tersebar}

Spektrum tersebar adalah teknologi penyebaran informasi dengan menggunakan pengkodean Pseudo-noise dan menggunakan bandwith yang lebih lebar [5], yaitu sebesar $125 \mathrm{MHz}$ dibandingkan dengan bandwith minimum sebesar $26 \mathrm{MHz}$ yang diperlukan pada sistem modulasi yang konvensional seperti AM, FM, FSK, atau PSK.

Prinsip utama komunikasi spektrum tersebar adalah pendudukan bandwidth jauh lebih lebar dari yang lain. Karena bandwidth yang lebih lebar, power spectral density lebih kecil, sehingga sinyal kelihatan seperti noise dalam kanal. Penyebaran dilakukan dengan menggabungkan sinyal data dan kode (code division multiple access), di mana kode ini independen terhadap data yang dikirimkan [6].

Ada beberapa teknik spektrum tersebar yang dapat digunakan. Yang paling populer adalah Direct Spectrum (DS), juga yang lumayan terkenal adalah Frequency-Hopping (FH). Kombinasi keduanya (DS/FH) menawarkan banyak keuntungan dan akan menjadi basis sistem yang diajukan.

\section{Pola Spektrum Tersebar}

Pemancar spektrum tersebar menggunakan pola random (acak) yang hanya dikenali oleh bagian penerima tertentu saja. Pola acak yang terbangkit tidak benar-benar acak, tetapi merupakan pola semi acak sehingga bagian penerima yang dituju dapat melakukan pembangkitan ulang untuk melindungi informasi yang dikirimkan [5]. Pola acak yang demikian dikenal sebagai semi acak (pseudorandom) atau dalam spektrum tersebar dikenal sebagai pseudo noise (PN).

\section{Sistem Spektrum Tersebar Direct Sequences.}

Blok diagram modulator direct sequence spread spectrum (DS-SS) diberikan pada gambar 1a. Suatu sinyal pembawa pertama kali dimodulasi oleh sinyal data $\mathrm{x}(\mathrm{t})$, selanjutnya sinyal termodulasi ini dimodulasi lagi dengan suatu sinyal yang memiliki tingkat penyebaran yang tinggi (wide band) $g(t)$. Suatu sinyal pembawa termodulasi oleh data dengan secara stabil atau tetap memiliki daya $P$, frekuensi sudut $\omega_{o}$ dan fase $\theta x(t)$ seperti berikut:

$$
S_{x}(t)=\sqrt{2 P} \cos \left[\omega_{o} t+\theta_{x} t\right]
$$

Proses modulasi berikutnya oleh penyebaran sinyal, $g(t)$ memberikan bentuk gelombang yang siap ditransmisi sebagai:

$$
S_{x}(t)=\sqrt{2 P} \cos \left[\omega_{o} t+\theta_{x} t+\theta_{g} t\right]
$$

Perhatikan bahwa fase pada carrier sekarang memiliki dua komponen:

- $\theta_{x}(t)$ : berkaitan dengan data

- $\theta_{g}(t)$ : berkaitan dengan penyebaran

Secara ekuivalen persamaan (1) dapat mewakili kondisi perkalian carrier dengan $x(t)$ yang merupakan deretan sinyal biner antipodal +1 dan -1 . Dalam hal ini nilai informasi 0 diwakili bentuk sinyal antipodal +1 sedangkan nila i informasi 1 diwakili oleh sinyal antipodal -1 . Persamaan (1) selanjutnya memiliki bentuk: 


$$
S_{x}(t)=\sqrt{2 P} x(t) \cos \omega_{o} t
$$

Hal yang sama kita perlakukan untuk persamaan (2) dimana $g(t)$ dinyatakan sebagai sekuen biner antipodal +1 dan -1 .

$$
S_{x}(t)=\sqrt{2 P} x(t) g(t) \cos \omega_{o} t
$$

Suatu modulator yang didasarkan pada persamaan (4) dapat diberikan dalam Gambar 1b Aliran pulsa data dan aliran penyebaran pulsa pada awalnya dikalikan, selanjutnya hasilnya $x(t) g(t)$ digunakan untuk memodulasi carrier.

Proses demodulasi pada sinyal DS/BPSK dilakukan dengan mengkorelasi atau memodulasi sinyal yang diterima dengan suatu replikasi penyebaran sinyal yang sudah tersinkronisasi $g\left(t-T d^{\prime}\right)$. Seperti pada Gambar 1c, dimana Td adalah estimasi penerima terhadap nilai delay propagasi Td dari pemancar menuju ke penerima [7].

\section{Orthogonal Frequency Division Multiplexing (OFDM)}

Orthogonal Frequency Division Multiplexing (OFDM) adalah suatu teknik transmisi multicarrier, yang membagi spektrum yang tersedia ke dalam beberapa pembawa, dimana masing-masing pembawa dimodulasi oleh aliran data dengan kecepatan yang lebih rendah [8]. OFDM serupa dengan FDMA dalam pengertian akses beberapa pemakai dicapai dengan membagi lebar pita yang tersedia ke dalam berbagai kanal. Akan tetapi, OFDM menggunakan spektrum yang jauh lebih efisien dengan mengatur jarak kanal subcarriernya.

\section{Carrier Spacing pada OFDM}

Jika ada dua sinyal berinterferensi satu sama lain terpisah pada beda frekuensi yang senilai kelipatan bulat dari bandwidth sinyal, maka hal ini tidak akan memberi efek. Kondisi ini dapat dikembangkan dengan memperbanyak jumlah sinyal carrier yang masing-masing terpisah dengan nilai frekuensi yang merupakan kelipatan bilangan bulat bandwidthnya. Sehingga dapat memanfaatkan bandwidth saluran secara keseluruhan tanpa mengganggu kinerja system [4], yang dikenal sebagai system orthogonal frequency division (OFDM).

\section{Prinsip dasar OFDM}

OFDM adalah sebuah teknik transmisi dengan banyak frekuensi (multicarrier), menggunakan Discrete Fourier Transfor (DFT) [8]. Bagan dasar dari OFDM ditampilkan pada Gambar.3.

Cara kerjanya adalah sebagai berikut. Deretan data informasi yang akan dikirim dikonversikan kedalam bentuk parallel, sehingga bila bit rate semula adalah $R$, maka bit rate di tiap-tiap jalur parallel adalah $R / M$ dimana $M$ adalah jumlah jalur parallel (sama dengan jumlah sub-carrier). Setelah itu, modulasi dilakukan pada tiap-tiap sub-carrier. Modulasi ini bisa berupa BPSK, QPSK, QAM atau yang lain, tapi ketiga teknik tersebut sering digunakan pada OFDM. Kemudian sinyal yang telah termodulasi tersebut diaplikasikan ke dalam Inverse Discrete Fourier Transform (IDFT), untuk pembuatan simbol OFDM. Penggunaan IDFT ini memungkinkan pengalokasian frekuensi yang saling tegak lurus (orthogonal), mengenai hal ini akan dijelaskan lebih lanjut. Setelah itu simbol-simbol OFDM dikonversikan lagi kedalam bentuk serial, dan kemudian sinyal dikirim melalui kanal [8].

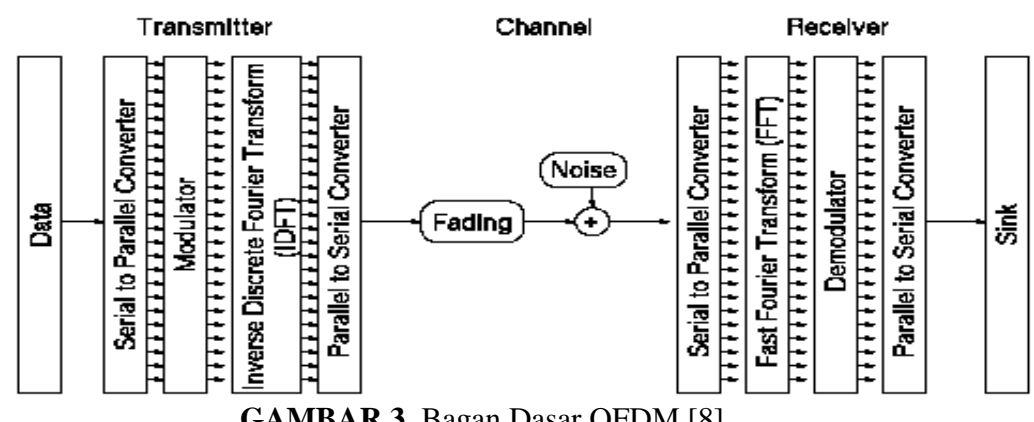

GAMBAR 3. Bagan Dasar OFDM [8].

Sedangkan pada stasiun penerima, dilakukan operasi yang berkebalikan dengan apa yang dilakukan di stasiun pengirim. Mulai dari konversi dari serial ke parallel, kemudian konversi 
sinyal parallel dengan Fast Fourier Transform (FFT), setelah itu demodulasi, konversi parallel ke serial, dan akhirnya kembali menjadi bentuk data informasi [8].

\section{Code Division Multiple Access}

Code Division Multiple Access (CDMA) adalah sebuah teknik spread spectrum yang tidak menggunakan kanal frekuensi maupun time slot. Dengan CDMA, data (biasanya data suara digital) digandakan dengan sebuah sinyal dengan bandwidth yang lebar yaitu pseudo random noise code (PN code). Semua user pada sistem CDMA menggunakan band frekuensi yang sama dan ditransmisikan secara simultan. Sinyal yang ditransmisikan kemudian dikembalikan dengan cara menkorelasikan sinyal yang diterima dengan PN code yang digunakan stasiun penerima [3].

\section{Modulasi Multi carrier}

Prinsip dari modulasi multicarrier adalah mentransmisikan sebuah blok data binary dengan menggunakan banyak ub-carrier [10]. Akibatnya akan terdapat banyak subchannel yang masingmasingnya bersifat independent dan spektrum frekuensinya terisolasi satu dengan yang lain.

Didalam prakteknya untuk mengimplementasikan sistem modulasi multicarrier adalah dengan cara melakukan Orthogonal Digital Transformation terhadap suatu blok data, yang dikenal dengan subchannelization [10].

\section{PERANCANGAN SIMULASI}

Pada Bab ini penulis akan menjelaskan tentang perancangan simulasi dari sistem OFDM dan MCCDMA. Dimulai dari blok diagram transmitter dan receiver OFDM, blok diagram transmitter dan receiver MC-CDMA hingga parameter-parameter yang berada dalam OFDM dan MCCDMA. Perancangan simulasi ini bertujuan untuk mensimulasikan sistem OFDM dan MCCDMA dengan efek Doppler pada kecepatan $20 \mathrm{~m} / \mathrm{s}$ pada kondisi kanal AWGN dan modulasi yang digunakan adalah BPSK (Binary Phase Shift Keying). Gambar 4 adalah gambar blok diagram dari OFDM dengan kanal AWGN.

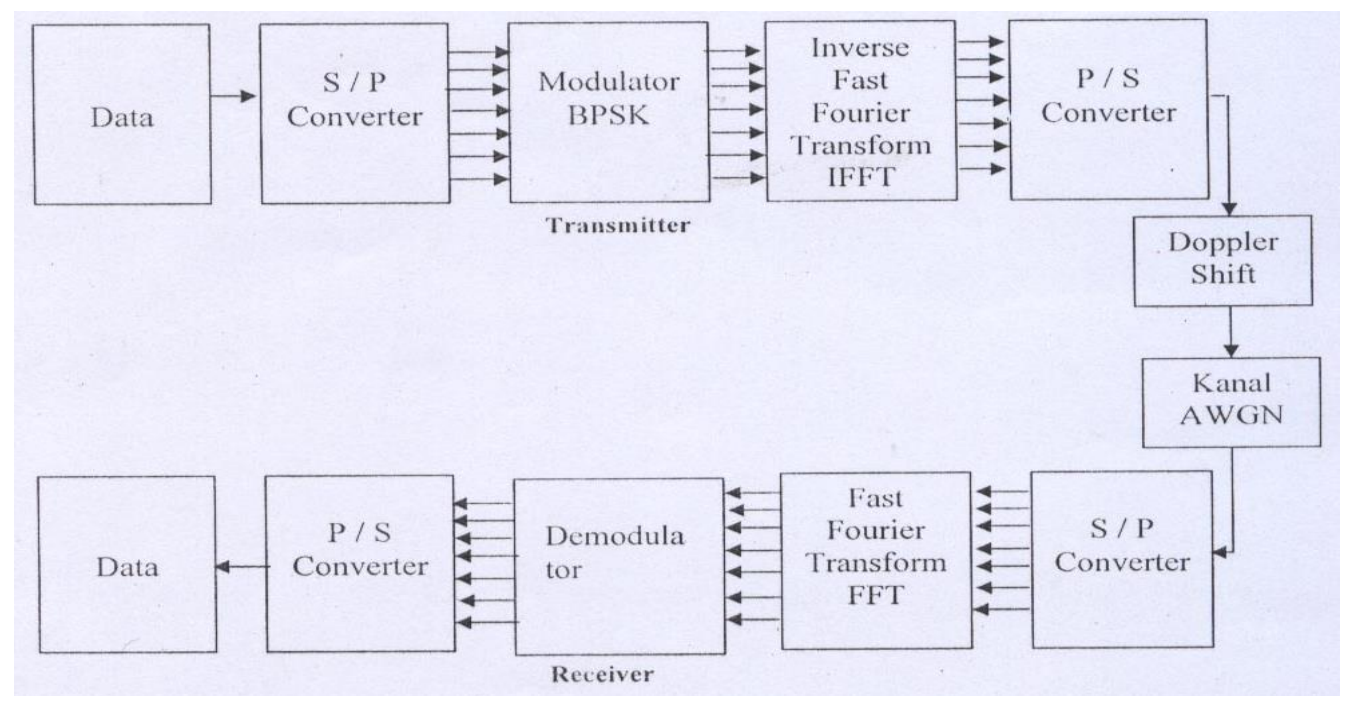

GAMBAR 4. Blok Diagram Transmitter dan Receiver OFDM [8].

Cara kerja blok diagram OFDM adalah menjelaskan deretan data informasi yang akan di kirim dikonversikan ke dalam bentuk paralel, Setelah itu, modulasi dilakukan pada tiap-tiap subcarrier, modulasi ini berupa BPSK. Kemudian sinyal yang telah termodulasi tersebut di aplikasikan ke dalam Inverse Fast Fourier Transform (IFFT). Penggunaan IFFT ini memungkinkan pengalokasian frekuensi yang saling tegak lurus (orthogonal). Setelah itu sinyal dikonversikan lagi kedalam bentuk serial, dan kemudian sinyal di teruskan kedalam Doppler Shift dimana sinyal akan dinormalisasi karena pergeseran frekuensi. Kemudian sinyal diteruskan ke dalam kanal, sinyal yang telah di terima di dalam kanal kemudian akan ditambahkan noise secara 
acak sehingga sinyal yang dihasilkan akan berupa data yang dikirimkan sebelumnya setelah itu sinyal tersebut akan di kirimkan.

Sedangkan pada sisi receiver, dilakukan operasi yang berkebalikan dengan apa yang di lakukan di sisi transmitter. Mulai dari konversi dari serial ke parallel, kemudian konversi sinyal parallel dengan Fast Fourier Transform (FFT), setelah itu demodulasi, konversi parallel ke serial, dan kembali menjadi bentuk data informasi [8].

\section{Blok Diagram Transmitter dan Receiver MC-CDMA}

Gambar 5 adalah gambar Blok diagram dari MC-CDMA dengan kanal AWGN.

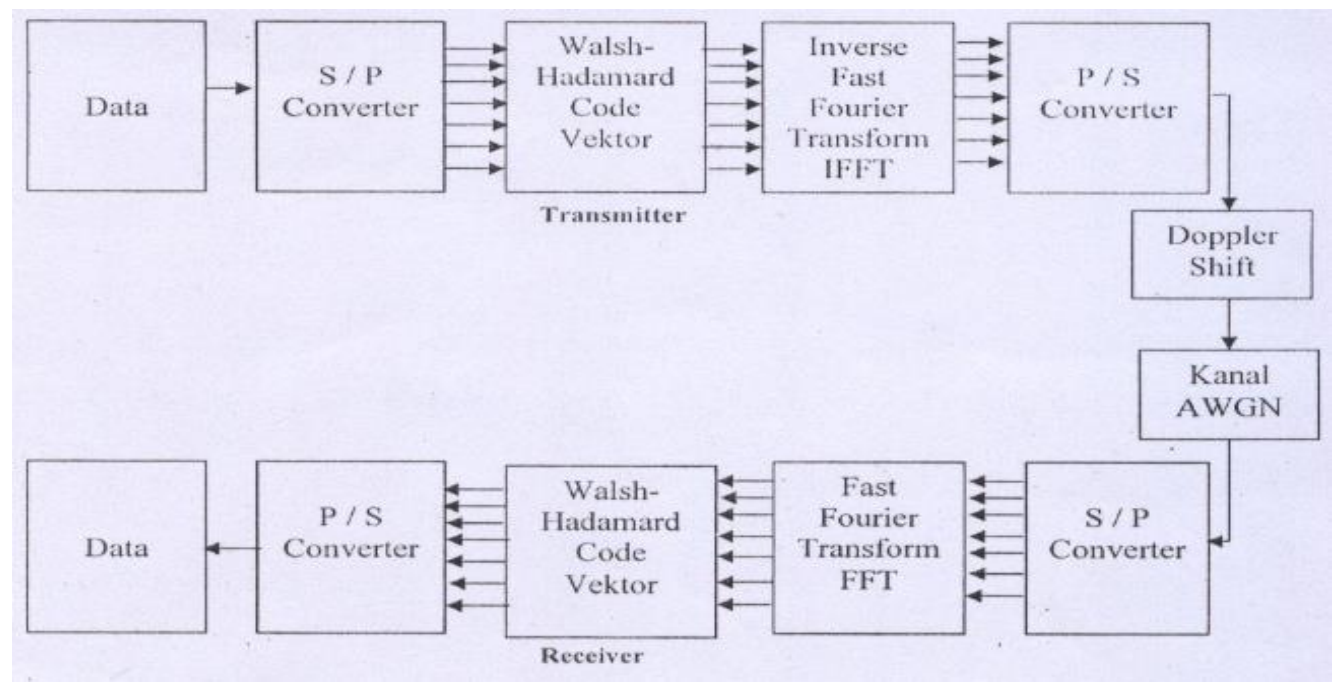

GAMBAR 5. Blok Diagram Transmitter dan Receiver MC-CDMA [8], [11].

Cara kerja blok diagram MCDMA adalah menjelaskan deretan data informasi yang akan di kirim dikonversikan ke dalam bentuk paralel Pada sisi Walsh-hadamard code Vector dilakukan pengkodean dengan menggunakan hadamard matriks, yang mana pada tiap baris kode matrik digunakan sebagai kode tiap sinyal dengan elemen biner.

Kemudian sinyal yang telah dikodekan tersebut di aplikasikan ke dalam Inverse Fast Fourier Transform (IFFT). Penggunaan IFFT ini memungkinkan pengalokasian frekuensi yang saling tegak lurus (orthogonal). Setelah itu sinyal dikonversikan lagi kedalam bentuk serial, dan kemudian sinyal di teruskan kedalam Doppler Shift dimana sinyal akan dinormalisasi karena pergeseran frekuensi. Kemudian sinyal diteruskan ke dalam kanal, sinyal yang telah di terima di dalam kanal kemudian akan ditambahkan noise secara acak sehingga sinyal yang dihasilkan akan berupa data yang dikirimkan sebelumnya setelah itu sinyal tersebut akan di kirimkan.

Sedangkan pada sisi receiver, dilakukan operasi yang berkebalikan dengan apa yang di lakukan di sisi transmitter. Mulai dari konversi dari serial ke parallel, kemudian konversi sinyal parallel dengan Fast Fourier Transform (FFT), setelah itu pengkodean walsh hadamard, konversi parallel ke serial, dan kembali menjadi bentuk data informasi [8].

Setiap simbol data pada sistem BPSK memodulasi fase pada frekuensi carrier yang lebih tinggi. Diagram berikut ini menunjukkan bagaimana bentuk time domaian dari system BPSK yang berupa carrier termodulasi oleh 8 simbol. Bit-bit data dapat berubah 1 atau 0 sesuai nilai informasi yang diwakilinya. Di dalam domain frekuensi, efek pergeseran fase dalam carrier berupa bentuk perluasan bandwidth yang yang dipakai sinyal BPSK pada suatu fungsi sinc. Nilai nol pada fungsi sinc terjadi pada frekuensi simbol interval [12].

\section{Kode Hadamard}

Kode Hadamard adalah teknik coding dengan cara memilih baris dari matriks hadamard. Kode Hadamard dihasilkan dengan menggunakan hadamard matriks, yang merupakan matrik segiempat dengan elemen biner, dan berdimensi kelipatan 2 [13].

Bentuk umumnya seperti pada persamaan (5). 


$$
\mathrm{H}_{2 \mathrm{~N}}=\left[\begin{array}{ll}
\boldsymbol{H}_{N} & \boldsymbol{H}_{N} \\
\boldsymbol{H}_{N} & \overline{\boldsymbol{H}_{N}}
\end{array}\right] ; \text { untuk } \mathrm{N}=2^{\mathrm{m}}
$$

dimana $\mathrm{m} \geq 0$ (integer positif) dan $\bar{H}_{N}$ merupakan inverter dari $H_{\mathrm{N}}[13]$.

Doppler Shift merupakan perubahan frekuensi atau pergeseran frekuensi radio yang disebabkan oleh gerakan stasiun penerima. Sinyal yang diterima memiliki persamaan (6) sebagai berikut [2]:

$$
y(n)=x(n) e^{\frac{j 2 \pi n \varepsilon}{N}}+w(n)
$$

di mana $\varepsilon$ adalah offset frekuensi yang dinormalisasi, dan diberikan dengan $f N T s, f$ adalah beda frekuensi antara frekuensi carrier yang dikirim dan yang diterima, $T$ adalah periode symbol subcarrier, $w(n)$ adalah AWGN yang dipakai dalam saluran [2].

Kemudian sinyal yang keluar dari modulator akan masuk ke dalam kanal dan tentu saja pada sinyal yang dibawa tersebut terdapat noise. Noise bisa dinyatakan sebagai sinyal elektrik yang muncul secara acak dan tidak terprediksi. Ketika sebuah variabel (nilai) acak ditambahkan ke suatu informasi yang dibawa oleh sebuah sinyal, informasi tersebut mungkin sekali akan mengalami perubahan atau suatu kondisi terburuk dapat terjadi dimana informasi tersebut tidak dapat dikenali sesuai bentuk aslinya [5]. Pada simulasi ini kanal yang digunakan adalah kanal AWGN

Demodulator merupakan proses kebalikan dari modulasi, yaitu melakukan pengubahan simbolsimbol kompleks hasil keluaran FFT menjadi bit-bit symbol. Pada keluaran sistem ini diikuti dengan proses parallel to serial data [2].

Hasil keluaran pada simulasi ini adalah berupa data yang diterima jumlah kesalahan bit yang diterima, Bit Error Rate. Dimana rumus untuk mencari BER adalah:

$$
B E R=\frac{\text { Jumlah Kesalahan bit yang diterima }}{\text { Bit yang diterima }}
$$

Bit Error Rate merupakan suatu ukuran kualitas sinyal yang diterima oleh suatu sistem digital [5]. Besarnya Bit Error Rate tergantung pada modulasi dan perbandingan antara sinyal yang diinginkan dengan sinyal pengganggu (derau atau interferensi ).

\section{HASIL SIMULASI DAN ANALISA}

Pada bab ini penulis akan menjelaskan tentang proses simulasi dan analisa OFDM dan MCCDMA dengan frekuensi carrier $900 \mathrm{MHz}$ dan $1800 \mathrm{MHz}$. Dalam simulasi ini menggunakan program JavaScript yang menggunakan teknik modulasi BPSK (Binary Phase Shift Keying) untuk mendapatkan suatu Bit Error Rate (BER).

Dalam melakukan simulasi ini penulis melakukan variasi pada frekuensi carrier dan parameterparameter pada kanal sehingga akan didapatkan suatu bit error rate yang paling kecil. Parameterparameter yang digunakan dalam simulasi ini diberikan pada tabel 1.

TABEL 1. Parameter Input.

\begin{tabular}{|c|c|}
\hline Parameter & Besarnya masukan \\
\hline Frekuensi Carrier & $900 \mathrm{MHz}, 1800 \mathrm{MHz}$ \\
\hline Speed & $20 \mathrm{~m} / \mathrm{s}$ \\
\hline Subscarrier & 64 \\
\hline Kanal & $\mathrm{AWGN}$ \\
\hline $\mathrm{E}_{\mathrm{b}} / \mathrm{N}_{\mathrm{o}}$ & $1-20 \mathrm{~dB}$ \\
\hline
\end{tabular}


Tabel 1 digunakan sebagai acuan untuk menjalankan simulasi OFDM dan MC-CDMA dengan kecepatan $20 \mathrm{~m} / \mathrm{s}$ dan menggunakan 2 jenis frekuensi carrier yang berbeda.

Hasil simulasi dan analisa dari kinerja sistem OFDM dan MC-CDMA dengan speed $20 \mathrm{~m} / \mathrm{s}$ pada frekuensi carrier $900 \mathrm{MHz}$ dapat dilihat pada data hasil simulasi yang terdapat pada tabel 2.

TABEL 2. Hasil simulasi dengan frekuensi carrier $900 \mathrm{MHz}$.

\begin{tabular}{|c|c|c|}
\hline \multirow{2}{*}{ Eb/No. $(\mathbf{d B})$} & \multicolumn{2}{|c|}{ Bit Error Rate } \\
\cline { 2 - 3 } & BPSK OFDM & BPSK MC-CDMA \\
\hline 1 & 0.13074 & 0.11 \\
\hline 2 & 0.11217 & 0.0895 \\
\hline 3 & 0.09523 & 0.0707 \\
\hline 4 & 0.08008 & 0.0538 \\
\hline 5 & 0.06675 & 0.0394 \\
\hline 6 & 0.05521 & 0.0274 \\
\hline 7 & 0.04535 & 0.0181 \\
\hline 8 & 0.03704 & 0.0113 \\
\hline 9 & 0.0301 & 0.0065 \\
\hline 10 & 0.02436 & 0.0035 \\
\hline 11 & 0.01964 & 0.0015 \\
\hline 12 & 0.0158 & 0.0006 \\
\hline 13 & 0.01268 & 0.0002 \\
\hline 14 & 0.01015 & $6 \mathrm{E}-05$ \\
\hline 15 & 0.00812 & $1 \mathrm{E}-05$ \\
\hline 16 & 0.00649 & $2 \mathrm{E}-06$ \\
\hline 17 & 0.00518 & $3 \mathrm{E}-07$ \\
\hline 18 & 0.00414 & $2.07 \mathrm{E}-08$ \\
\hline 19 & 0.0033 & $9.89 \mathrm{E}-09$ \\
\hline 20 & 0.00263 & $2.6 \mathrm{E}-11$ \\
\hline & & \\
\hline
\end{tabular}

Tabel 2 merupakan hasil simulasi dengan frekuensi carrier $900 \mathrm{MHz}$ dengan Doppler spread sebesar $60 \mathrm{~Hz}$ s dengan kecepatan $20 \mathrm{~m} / \mathrm{s}$ serta $\mathrm{E}_{\mathrm{b}} / \mathrm{N}_{\mathrm{o}}$ yang berbeda-beda dan akibat adanya derau maka akan dihasilkan suatu Bit Error yang berbeda-beda hingga dihasilkan suatu Bit Error yang paling kecil. Berdasarkan dengan hasil tabel dari hasil simulasi maka grafiknya dapat dilihat pada gambar 8 di bawah ini.

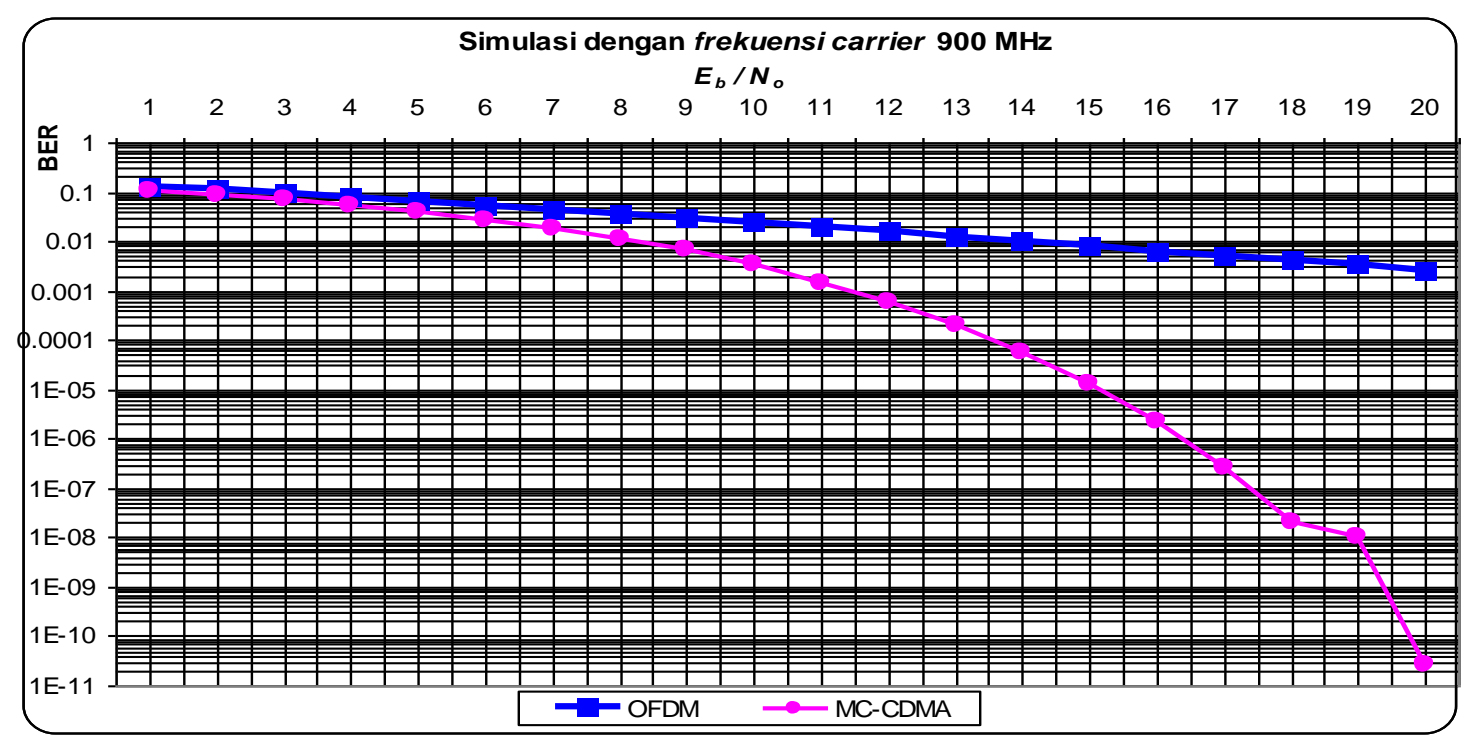

GAMBAR 8. Grafik BER dengan frekuensi carrier $900 \mathrm{MHz}$. 
Berdasarkan dari hasil simulasi tabel 2 dan gambar 8 memperlihatkan bahwa Bit Error pada OFDM dan MC-CDMA akan mencapai hasil yang paling kecil pada saat $\mathrm{E}_{\mathrm{b}} / \mathrm{N}_{\mathrm{o}}$ pada posisi 20 dB. Dapat dilihat bahwa Bit Error pada MC-CDMA mencapai hasil yang paling kecil. Kedua nilai BER diatas, didapat dalam satu simulasi atau bukan simulasi yang terpisah.

Hasil simulasi dan analisa dari kinerja sistem OFDM dan MC-CDMA dengan speed $20 \mathrm{~m} / \mathrm{s}$ pada frekuensi carrier $1800 \mathrm{MHz}$ dapat dilihat pada data hasil simulasi yang terdapat pada tabel 3 .

TABEL 3. Hasil simulasi dengan frekuensi carrier $1800 \mathrm{MHz}$.

\begin{tabular}{|c|c|c|}
\hline \multirow{2}{*}{$\mathbf{E}_{\mathbf{b}}$ /No. $(\mathbf{d})$} & \multicolumn{2}{|c|}{ Bit Error Rate } \\
\hline & BPSK OFDM & BPSK MC-CDMA \\
\hline 1 & 0.13087 & 0.1103 \\
\hline 2 & 0.1123 & 0.0898 \\
\hline 3 & 0.09537 & 0.0709 \\
\hline 4 & 0.08022 & 0.0541 \\
\hline 5 & 0.06688 & 0.0396 \\
\hline 6 & 0.05534 & 0.0276 \\
\hline 7 & 0.04548 & 0.0183 \\
\hline 8 & 0.03716 & 0.0114 \\
\hline 9 & 0.03022 & 0.0066 \\
\hline 10 & 0.02448 & 0.0036 \\
\hline 11 & 0.01976 & 0.0015 \\
\hline 12 & 0.01592 & 0.0006 \\
\hline 13 & 0.0128 & 0.0002 \\
\hline 14 & 0.01027 & $6 \mathrm{E}-05$ \\
\hline 15 & 0.00824 & $1 \mathrm{E}-05$ \\
\hline 16 & 0.00661 & $3 \mathrm{E}-06$ \\
\hline 17 & 0.0053 & 0 \\
\hline 18 & 0.00425 & 0 \\
\hline 19 & 0.00342 & 0 \\
\hline 20 & 0.00275 & 0 \\
\hline & & \\
\hline & & \\
\hline
\end{tabular}

Tabel 3 merupakan hasil simulasi dengan frekuensi carrier $1800 \mathrm{MHz}$ dengan Doppler spread sebesar $120 \mathrm{~Hz}$ dengan kecepatan $20 \mathrm{~m} / \mathrm{s}$ serta $\mathrm{E}_{\mathrm{b}} / \mathrm{N}_{\mathrm{o}}$ yang berbeda-beda dan akibat adanya derau maka akan dihasilkan suatu Bit Error yang berbeda-beda hingga dihasilkan suatu Bit Error yang paling kecil. Berdasarkan dengan hasil tabel dari hasil simulasi maka grafiknyadapat dilihat di bawah ini.

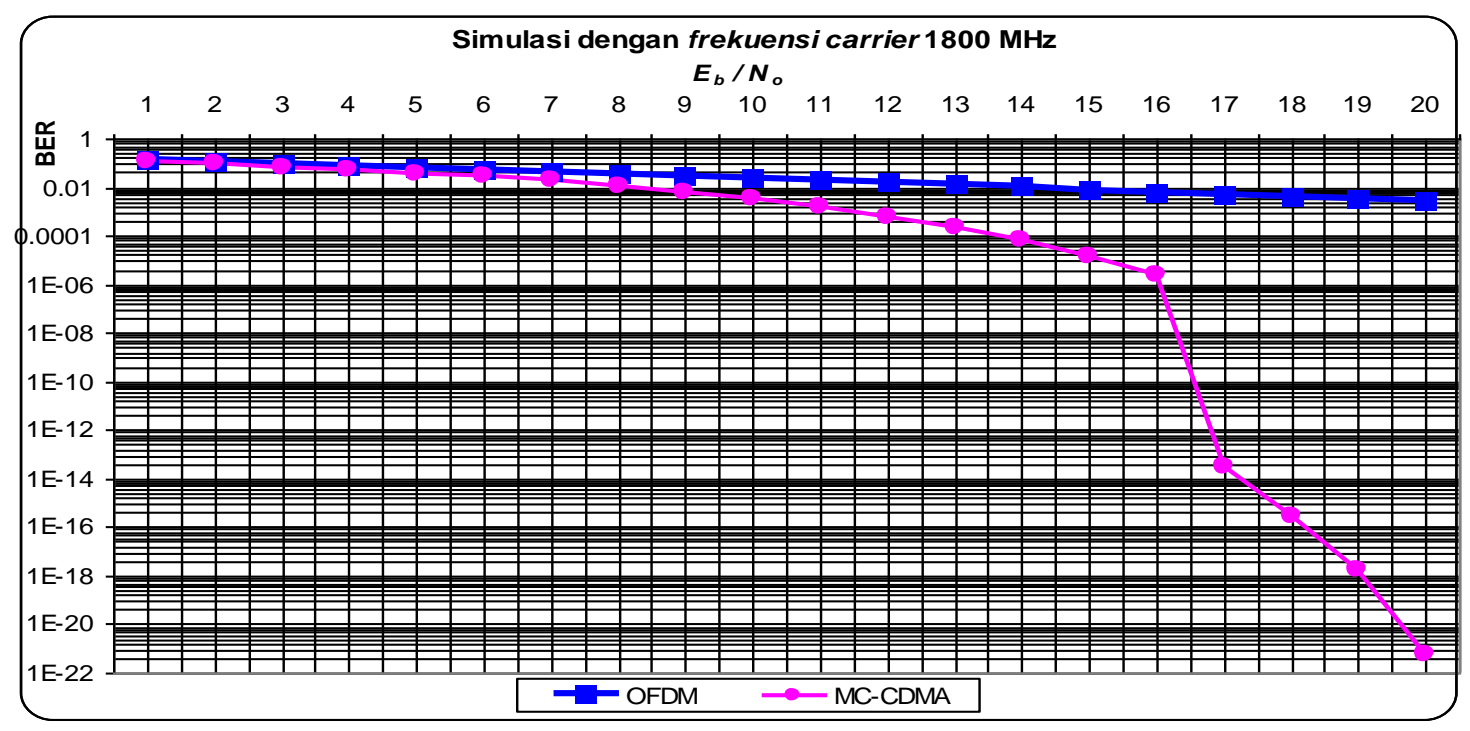

GAMBAR 9. Grafik BER dengan frekuensi carrier $1800 \mathrm{MHz}$. 
Berdasarkan dari hasil simulasi 3abel 3 dan gambar 9 memperlihatkan bahwa Bit Error pada OFDM dan MC-CDMA akan mencapai hasil yang paling kecil pada saat $\mathrm{E}_{\mathrm{b}} / \mathrm{N}_{\mathrm{o}}$ pada posisi 17 dB. Dapat dilihat bahwa Bit Error pada MC-CDMA mencapai hasil yang paling kecil. Kedua nilai BER diatas, didapat dalam satu simulasi atau bukan simulasi yang terpisah.

Analisa hasil simulasi OFDM dan MC-CDMA dengan menggunakan teknik modulasi BPSK yang menggunakan frekuensi Carrier $900 \mathrm{MHz}$ dan $1800 \mathrm{MHz}$ yang mempunyai batas interval $\mathrm{E}_{\mathrm{b}} / \mathrm{N}_{\mathrm{o}} 1$ sampai $20 \mathrm{~dB}$ berdasarkan grafik perbandingan nilai BER pada OFDM dan MC-CDMA. Analisa dengan menggunakan frekuensi carrier $900 \mathrm{MHz}$ akan menghasilkan Doppler spread sebesar $60 \mathrm{~Hz}$. Berdasarkan grafik BER pada Gambar 8 dan tabel pada Tabel. 2 bahwa nilai BER yang dihasilkan pada MC-CDMA jauh lebih rendah daripada BER pada OFDM. Ini karena MCCDMA menggunakan bentuk rangkaian Walsh Hadamard dengan sebuah pengoperasian marik NxN untuk menghindari kesalahan bit yang berlebihan pada subcarrier [11].

Analisa dengan menggunakan frekuensi carrier $1800 \mathrm{MHz}$ akan menghasilkan Doppler spread sebesar $120 \mathrm{~Hz}$. Berdasarkan grafik BER pada gambar 9 dan pada tabel.3 bahwa nilai BER yang dihasilkan pada MC-CDMA jauh lebih rendah daripada BER pada OFDM. Bahkan untuk mendapatkan nilai BER $=0$ sistem hanya memerlukan nilai $\mathrm{E}_{\mathrm{b}} / \mathrm{N}_{\mathrm{o}}$ sebesar $17 \mathrm{~dB}$, sedangkan untuk OFDM BER yang didapat pada $\mathrm{E}_{\mathrm{b}} / \mathrm{N}_{\mathrm{o}}$ sebesar $20 \mathrm{~dB}$ hanya sebesar 0.00275. Ini karena MC-CDMA menggunakan bentuk rangkaian Walsh Hadamard dengan sebuah pengoperasian matrik $\mathrm{N} \times \mathrm{N}$ untuk menghindari kesalahan bit yang berlebihan pada subcarrier [11].

\section{KESIMPULAN}

Dari simulasi tampak bahwa sistem OFDM dibanding MC-CDMA lebih bagus MC-CDMA, baik pada frekuensi carrier $900 \mathrm{MHz}$ maupun $1800 \mathrm{MHz}$. Sebagai contoh, pada nilai $\mathrm{E}_{\mathrm{b}} / \mathrm{N}_{\mathrm{o}}$ sebesar $20 \mathrm{~dB}$ pada frekuensi carrier $900 \mathrm{MHz}$, maka nilai BER pada OFDM $=0.00263$, sedangkan BER pada MC-CDMA $=2.6 \mathrm{E}-11$. sedangkan pada frekuensi carrier $1800 \mathrm{MHz}$ BER pada OFDM = 0.00275 dan BER pada MC-CDMA $=0$.

Dari hasil simulasi bahwa MC-CDMA dapat beroperasi dalam kanal dengan waktu yang lama dengan tingkat kesalahan bit (bit error) yang memuaskan.

\section{REFERENSI}

[1] Http://wireless.per.nl/reference/chaptr0 5/ofdm/ofdm.htm

[2] Ruliyanto," Unjuk Kerja ICI Self Cancellation pada Sistem Fast-OFDM “, Thesis Pasca Sarjana UI, Depok 2003.

[3] Muhyil Asyrof," Simulasi kanal Rayleigh Fading pada sistem komunikasi Nirkabel",Skripsi UNAS, Jakarta 2005.

[4] Http://www.google.com./ofdm/teknologi digital dimasa datang, SYSCOM /New_Mod digital/.doc

[5] Eko Sukrisna," Analisa dan Simulasi sistem Bluetooth dengan frekuensi hopping pada kanal AWGN", Skripsi UNAS, Jakarta 2005.

[6] J. Meel, Ir, Studiedag Spread Spectrum, DeNayyer Instituut, oktober 1999,pp.9-14

[7] Http://www.google.com./spread spektrum/teknologi digital dimasa datang. Sistem Modulasi Spread Spektrum, SYSCOM/New_Moddigital/Bab 3_fsk. Doc

[8] Http://www.google.com./ofdm/mengenal teknologi frequency division multiplexing (ofdm) pada komunikasi wireless/.com

[9] Jery D. Gibson," Code division Multiple Acces", 1996

[10] R. Prasad, S Hara," An overview of multicarrier CDMA", IEE Comunication Magazine, Desember 1997.

[11] Http://wireless.per.nl/reference/chaptr05/mccdma/mccdma.htm

[12] Http://www.google.com./ofdm/teknik single user dan multi user. /com

[13] Http://www.google.com./chanel coding dan matriks. /com 